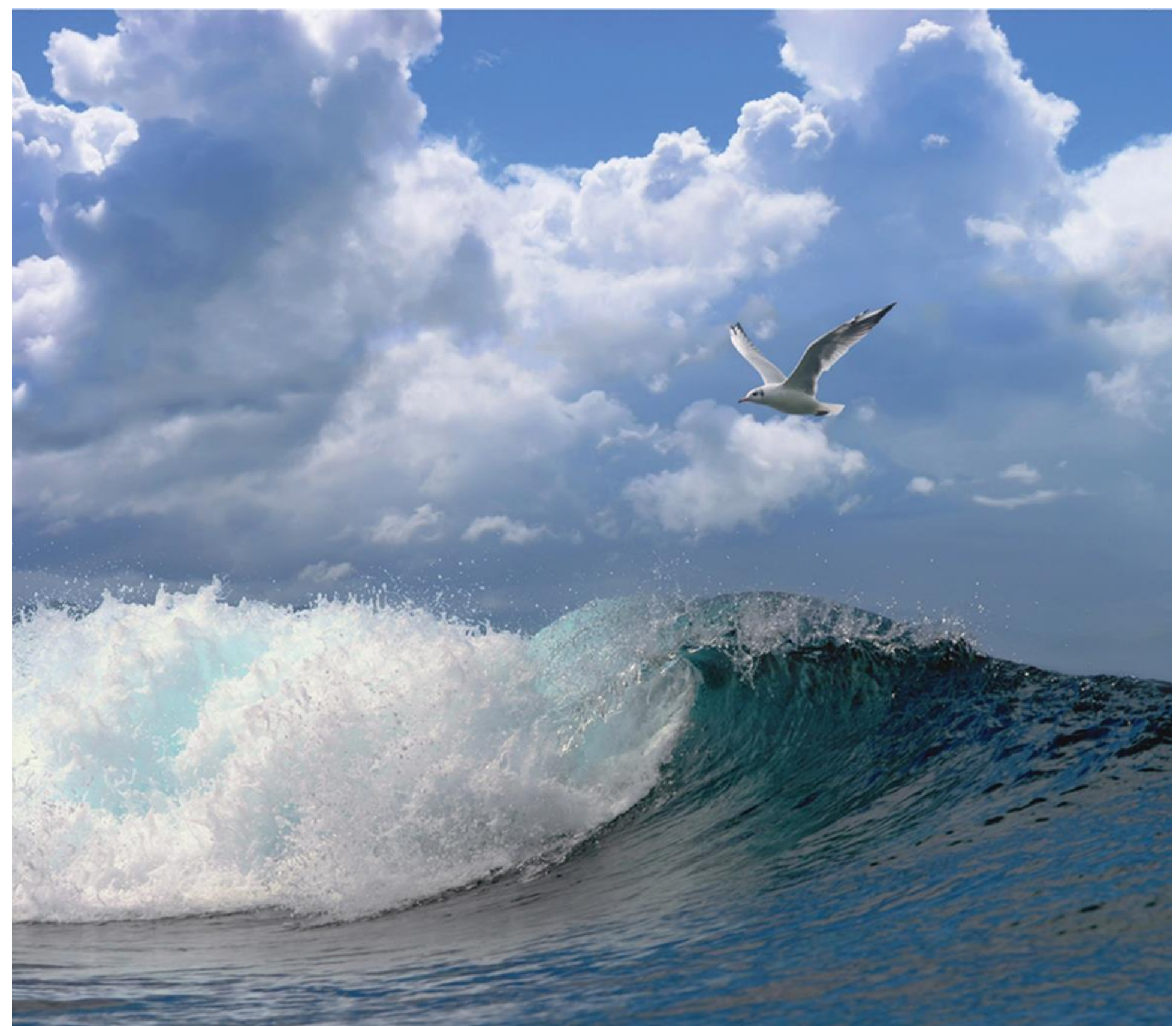

\title{
Cruiserapport scheepstellingen van zeevogels op het Friese Front, 2018
}




\section{Cruiserapport scheepstellingen van zeevogels op het Friese Front, 2018}

Auteurs: $\quad$ SCV Geelhoed, S Lagerveld, MF Leopold \& JP Verdaat

Publicatiedatum: 25 oktober 2019

Dit onderzoek is uitgevoerd door Wageningen Marine Research in opdracht van en gefinancierd door het Ministerie van Economische Zaken, in het kader van het Beleidsondersteunend onderzoekthema 'Marien' (projectnummer BO-11-018.02-061)

Wageningen Marine Research, Den Helder, 25 oktober 2019

Wageningen Marine Research rapport C098/19 
SCV Geelhoed, S Lagerveld, MF Leopold \& JP Verdaat, 2019. Cruiserapport scheepstellingen van zeevogels op het Friese Front, 2019. Wageningen Marine Research Wageningen UR (University \& Research centre), Wageningen Marine Research rapport C098/19, 28 blz.

Keywords: ESAS telling, grote jager, kleine mantelmeeuw, grote mantelmeeuw, zeevogel, alk, zeekoet, verspreiding, Friese Front

Opdrachtgever: Ministerie van Landbouw, Natuur en Voedselkwaliteit

T.a.v.: Sjaak Vonk

Postbus 20401

2500 EK Den Haag

BAS code BO-43-021.02-005.

This report can be downloaded for free from https://doi.org/10.18174/504274

Wageningen Marine Research provides no printed copies of reports

Wageningen Marine Research Wageningen UR is ISO 9001:2015 gecertificeerd.

(c) 2017 Wageningen Marine Research Wageningen UR

Wageningen Marine Research, onderdeel van Stichting Wageningen Research KvK nr. 09098104,

IMARES BTW nr. NL 8113.83.696.B16

Code BIC/SWIFT address: RABONL2U

IBAN code: NL 73 RABO 0373599285
De Directie van Wageningen Marine Research is niet aansprakelijk voor gevolgschade, noch voor schade welke voortvloeit uit toepassingen van de resultaten van werkzaamheden of andere gegevens verkregen van Wageningen Marine Research opdrachtgever vrijwaart Wageningen Marine Research van aanspraken van derden in verband met deze toepassing.

Dit rapport is vervaardigd op verzoek van de opdrachtgever hierboven aangegeven en is zijn eigendom. Niets uit dit rapport mag weergegeven en/of gepubliceerd worden, gefotokopieerd of op enige andere manier gebruikt worden zonder schriftelijke toestemming van de opdrachtgever. 


\section{Inhoud}

Samenvatting

$1 \quad$ Inleiding

$2 \quad$ Kennisvraag

3 Methoden $\quad 7$

$\begin{array}{lll}3.1 & \text { Studiegebied en survey design } & 7\end{array}$

$\begin{array}{ll}3.2 \text { Vogeltellingen } & 7\end{array}$

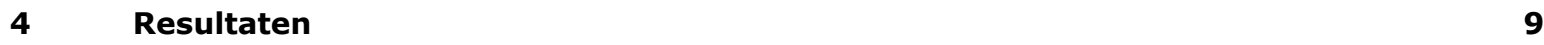

$\begin{array}{llr}4.1 & \text { Surveyverslag } & 9\end{array}$

4.2 Waarnemingsomstandigheden $r$

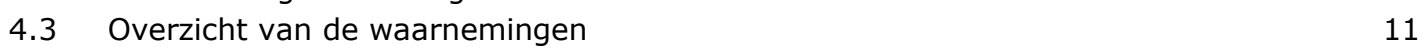

4.4 Soortbesprekingen $\quad 11$

4.4.1 Noordse Stormvogel 11

$\begin{array}{ll}4.4 .2 & \text { Jan-van-Gent }\end{array}$

4.4.3 Zwarte Zee-eend 13

$\begin{array}{lll}4.4 .4 & \text { Grote Jager } & 14\end{array}$

4.4.5 Kleine Mantelmeeuw 14

4.4.6 Grote Mantelmeeuw 15

$\begin{array}{lll}4.4 .7 & \text { Drieteenmeeuw } & 16\end{array}$

$\begin{array}{lll}4.4 .8 \text { Alk } & 18\end{array}$

$\begin{array}{lll}4.4 .9 & \text { Zeekoet } & 18\end{array}$

$\begin{array}{ll}4.4 .10 & \text { Bruinvis }\end{array}$

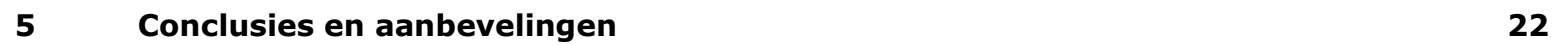

$\begin{array}{llr}6 & \text { Literatuur } & 23\end{array}$

$7 \quad$ Bijlagen Aantallen waargenomen vogels en zeezoogdieren $\quad 24$

$8 \quad$ Kwaliteitsborging $r$

$\begin{array}{lr}\text { Verantwoording } & 27\end{array}$ 


\section{Samenvatting}

Het Friese Front en de Bruine Bank zijn twee nieuwe Vogelrichtlijngebieden in de Noordzee. Het Friese Front is aangewezen voor de Zeekoet. De Bruine Bank wordt waarschijnlijk aangewezen voor Zeekoet en Alk. Om te bepalen of de instandhoudingsdoelstellingen voor deze soorten worden gehaald, moeten de aantallen van deze soorten gemonitord worden. Monitoring van zeevogels in het Nederlandse deel van de Noordzee vindt plaats met behulp van MWTL-vliegtuigtellingen. Alken en Zeekoeten kunnen vanuit de lucht echter lastig van elkaar te onderscheiden zijn. Vanaf schepen is de herkenning eenvoudiger.

Het onderhavige BO-project 'scheepstellingen zeevogels' dat in 2016-2019 loopt, heeft tot doel inzicht te geven in de aantallen van Alken en Zeekoeten in beide gebieden enerzijds, en anderzijds in de veranderingen in aantalsverhouding tussen beide soorten gedurende het jaar om de MWTLvliegtuigtellingen te kunnen calibreren.

In 2018 zijn twee scheepssurveys op het Friese Front uitgevoerd (24-28 jul, 25-28 nov). De julisurvey was succesvol, terwijl de novembersurvey door slechte weersomstandigheden afgebroken moest worden.

Tijdens de julisurvey werden 13650 individuen verdeeld over 25 verschillende vogelsoorten op het Friese Front geteld. Zeekoet $(n=6127)$, Kleine Mantelmeeuw $(n=2680)$, Drieteenmeeuw $(n=1544)$, Noordse Stern/Visdief $(n=1176)$ en Jan-van-Gent $(n=1175)$ domineerden de telling. Daarnaast werden 143 individuen verdeeld over drie soorten zeezoogdieren (Dwergvinvis, Bruinvis en Grijze Zeehond) geregistreerd.

In november werden op het Friese Front 1864 individuen verdeeld over 15 verschillende vogelsoorten geteld. Zeekoet $(n=717)$, Alk $(n=697)$ en Drieteenmeeuw $(n=190)$ waren de dominante soorten. Daarnaast werden vijf Bruinvissen gezien.

Tijdens beide surveys was Zeekoet de talrijkste soort. In juli werden de hoogste aantallen Zeekoeten op het Friese Front geteld, terwijl Alken hier ontbraken. In november waren de aantallen Zeekoeten lager, maar waren Alken talrijker. De verhouding Alk:Zeekoet was in november 1:1.

Behalve van alkachtigen werden aanvullende gegevens verzameld over de aantallen van potentieel kwalificerende N2000-soorten Grote Mantelmeeuw (met name nov) en Kleine Mantelmeeuw (met name jul). De aantallen van de potentieel kwalificerende N2000-soort Grote Jager waren tijdens alle 2018surveys laag.

De resultaten van de surveys in 2016 en 2017 zijn gepubliceerd in Geelhoed \& Leopold (2017) en Geelhoed et al (2018). Dit rapport geeft een beknopt overzicht van de resultaten van de surveys in 2018. Eind 2019 worden de resultaten van alle surveys nader uitgewerkt en gepresenteerd in een eindrapportage. 


\section{Inleiding}

Het Friese Front en de Bruine Bank zijn twee nieuwe Vogelrichtlijngebieden op de Noordzee. Het Friese Front is aangewezen voor de Zeekoet. De Bruine Bank wordt waarschijnlijk aangewezen voor Zeekoet en Alk. Om te bepalen of de instandhoudingsdoelstellingen voor deze soorten worden gehaald, moeten deze soorten goed gemonitord worden. In deel 2 van de Mariene Strategie (het KRMMonitoringprogramma) zijn afspraken gemaakt over de monitoring van zeevogels. Het voorkomen van zeevogels in het Nederlandse deel van de Noordzee wordt gemonitord met behulp van MWTLvliegtuigtellingen.

Alken en Zeekoeten lijken sterk op elkaar. Er bestaat onzekerheid over de mogelijkheid om beide soorten vanuit een vliegtuig op de MWTL-vlieghoogte van elkaar te onderscheiden. Vanaf een schip zijn deze beide alkachtigen goed van elkaar te onderscheiden. Om de bruikbaarheid van de MWTL-tellingen voor het monitoren van beide soorten te vergroten is een antwoord op de volgende vraag noodzakelijk: Kan er op basis van scheepstellingen een 'standaard' aantalsverdeling tussen Alk en Zeekoet in een bepaalde periode vastgesteld worden, waarmee de onzekerheid in de met vliegtuig getelde aantallen kan worden verkleind?

Eerder is door de voorloper van Wageningen Marine Research, IMARES, een 'parallelle scheepstelling' uitgevoerd om te bezien of daarmee tot 'ijking' van de vliegtuigtellingen gekomen kon worden. Dit was op basis van die tellingen niet mogelijk. Meerdere jaren van dergelijke scheepstellingen bieden mogelijk wel uitkomst. In het BO-project 'scheepstellingen zeevogels' zijn dergelijke scheepssurveys in de jaren 2016-2018 uitgevoerd.

Dit BO-onderzoek heeft tot doel inzicht te geven in enerzijds de aantallen van Alken en Zeekoeten in de gebieden Friese Front en Bruine Bank, en anderzijds in de veranderingen in aantalsverhouding tussen beide soorten gedurende het jaar. Deze gegevens zullen gebruikt worden om de MWTL-vliegtuigtellingen te calibreren.

De scheepstellingen zijn primair gericht op Alken en Zeekoeten, maar alle soorten worden geteld, waaronder potentieel kwalificerende N2000-soorten, Grote Jager, Kleine Mantelmeeuw en Grote Mantelmeeuw. Voor deze soorten zijn op dit moment geen tellingen van voldoende kwaliteit beschikbaar om te bepalen of ze kwalificeren als selectiesoort of als begrenzingssoort voor (een van) beide N-2000 gebieden Friese Front of Bruine Bank (Leopold \& van der Wal 2015, Leopold et al. 2015).

In dit cruiserapport worden de surveyresultaten beschreven van de surveys die in 2018 op het Friese Front zijn uitgevoerd. In de loop van 2019 wordt gerapporteerd over het gehele BO-project. 


\section{Kennisvraag}

In het BO-project scheepstellingen zeevogels worden antwoorden gezocht op een drietal vragen:

1) Wat is de aantalsverdeling tussen Alk en Zeekoet in twee gebieden in verschillende perioden van het jaar teneinde resultaten van MWTL-vliegtuigtellingen te corrigeren/calibreren?

2) Welke aantallen Alken en Zeekoeten komen voor op het Friese Front en op de Bruine Bank?

3) Welke aantallen Kleine Mantelmeeuwen, Grote Mantelmeeuwen en Grote Jagers komen voor op het Friese Front en op de Bruine Bank?

In dit cruiserapport worden de resultaten beschreven van de surveys die in 2018 op het Friese Front zijn uitgevoerd. In de loop van 2019 wordt gerapporteerd over het gehele BO-project. 


\section{Methoden}

\subsection{Studiegebied en survey design}

De surveys in 2018 werden uitgevoerd op het Friese Front, in juli en in november. Het Friese Front ligt ten noordnoordwesten van de westelijke Waddeneilanden (figuur 1).

De surveys werden uitgevoerd op vooraf vastgestelde transecten. De transecten sluiten zo veel mogelijk aan bij eerder getelde transecten. De lengtes van de transecten waren afgestemd op haalbare afstanden gegeven de daglengtes, en windkracht en windrichting tijdens de wintersurveys en komen overeen met de transecten die tijdens eerdere surveys in 2009 zijn gebruikt (Leopold et al. 2009). De ligging van de oostelijke transecten is licht aangepast om de surveytijd in de scheepvaartroutes te beperken.

\subsection{Vogeltellingen}

Tellingen zijn verricht volgens het standaard ESAS protocol (Tasker et al. 1984). Alle vogels en zeezoogdieren binnen een transect-strook van $300 \mathrm{~m}$ breed werden geteld. Daarnaast werd ook het gedrag genoteerd, waarbij de definities en codes van Camphuysen \& Garthe (2004) werden gebruikt. Tellingen werden uitgevoerd door twee waarnemersteams, ieder vanuit een observatiebox bovenop de brug, vanaf minstens 10 meter boven de waterlijn. Zo mogelijk is aan beide kanten van het schip een strook van 300 meter breed geteld, verdeeld in vier afstandsbanden: A (0-50m), B (50-100m), C (100$200 \mathrm{~m}$ ) en $D(200-300 \mathrm{~m})$, dwars op de gevaren lijn. Vliegende vogels werden tijdens snapshots op iedere gehele minuut geteld, tot 300 meter voor de boeg: de afstand die het schip in één minuut aflegt. Waarnemingen werden per 5 minuten samen genomen. De tellingen werden gedurende de daglichtperiode uitgevoerd. Bij slechte omstandigheden (sterk tegenlicht, harde tegenwind, regen) werd slechts geteld aan de zijde van het schip met de beste omstandigheden (licht, wind, regen mee). 


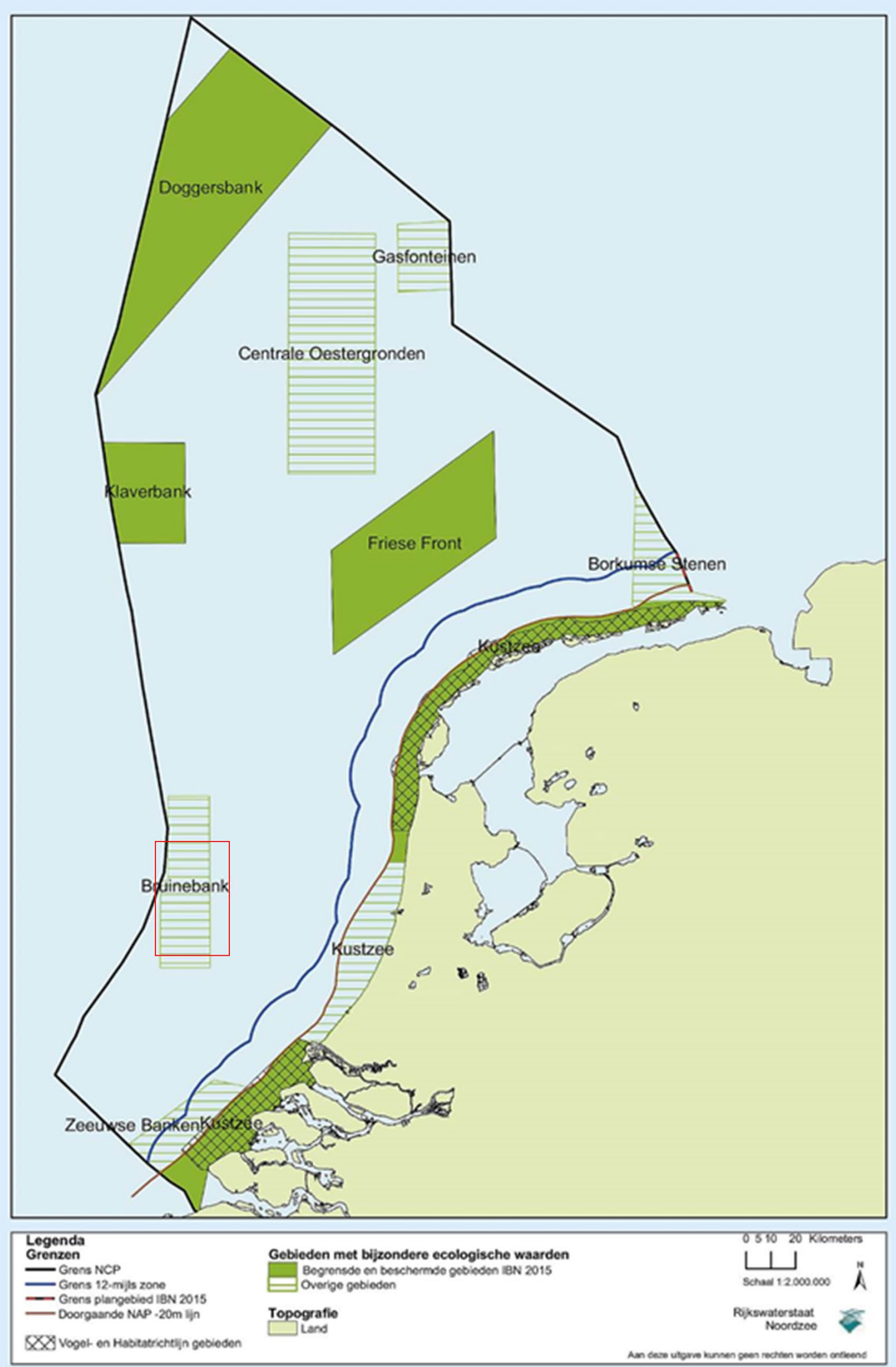

Figuur 1. Ligging van het Friese Front. Bron: Rijkswaterstaat. Het gearceerde gebied "Bruine Bank" is ingetekend volgens Lindeboom et al. (2005). De rode contour hier overheen geeft het door van Bemmelen et al. (2012) gedefinieerde MCC-gebied 9 weer. 


\section{Resultaten}

\subsection{Surveyverslag}

De eerste survey van 2018 vond plaats in de periode 24-28 juli vanaf de Glomar Pride. Waarnemers: Jos van de Berg, Steve Geelhoed, Mardik Leopold en Hans Verdaat. Dinsdagochtend vertrek uit de haven van Den Helder. Begonnen met de tellingen nadat het schip de Verkenner van het Schulpengat was gepasseerd en koers had gezet naar het meest zuidoostelijke punt van de transecten op het Friese Front. Geteld tot het noordoostelijk gelegen punt. Hier de volgende ochtend begonnen met tellen van de centrale noord-zuid liggende transecten. Donderdag de resterende westelijke transecten geteld. De resterende scheepstijd gebruikt om 's nachts naar de zuidoostpunt van de Botney Cut te varen en daar vier transecten te tellen. Zaterdagochtend ontscheping in Den Helder.

De tweede survey vond plaats in de periode 25-28 november vanaf de Glomar Viking. Waarnemers: Steve Geelhoed, Sander Lagerveld, Mardik Leopold en Hans Verdaat. De weersvoorspellingen waren niet al te goed, maar de survey kon niet meer verschoven worden. Zondagavond vertrek uit de haven van Den Helder om 's ochtends na zonsopkomst met tellingen op het Friese Front te beginnen. De eerste twee dagen bleef de wind beperkt tot windkracht 5 Beaufort. De voorspelde stormachtige wind stak woensdag op en stuwde de golfhoogte zo op dat tellen -zelfs met meewind- onmogelijk werd. Aangezien de wind pas in het weekend iets zou luwen, is de survey gestaakt en werd tegen de wind in koers gezet naar de haven. Woensdagvond ontscheping in Den Helder.

\subsection{Waarnemingsomstandigheden}

Tijdens de twee surveys zijn in totaal 1182 5-mintellingen uitgevoerd. In totaal is $1667.4 \mathrm{~km}$ geteld, hetgeen met een telstrook van twee maal 300 meter overeenkomt met een oppervlakte van $500.1 \mathrm{~km}^{2}$ (tabel 1). De weergegeven waarnemingsinspanning is inclusief de getelde transecten buiten het N2000gebied Friese Front. Zowel het aantal tellingen als de getelde oppervlakte per survey zijn gedeeltelijk afhankelijk van de daglengte en de waarnemingsomstandigheden.

Tabel 1. Waarnemingsinspanning per dag; weergegeven is het aantal 5-mintellingen, de getelde oppervlakte en de getelde afstand.

\begin{tabular}{llll}
\hline Datum & 5-min telling & Oppervlak $\left(\mathbf{k m}^{2}\right)$ & Afstand $(\mathbf{k m})$ \\
\hline \multicolumn{2}{l}{ Friese } & Front juli \\
\hline 24 & 176 & 74.1 & 247.0 \\
25 & 242 & 95.6 & 318.7 \\
26 & 260 & 105.6 & 352.1 \\
27 & 232 & 93.1 & 310.2 \\
\hline Totaal & 910 & 368.4 & 1228.0 \\
\hline \multicolumn{7}{l}{ Friese } & Front november & \\
\hline 26 & 157 & 75.0 & 250.2 \\
27 & 115 & 56.7 & 189.2 \\
\hline \multicolumn{7}{l}{ Totaal } & 272 & 131.7 & 439.4 \\
\hline
\end{tabular}


Seastate

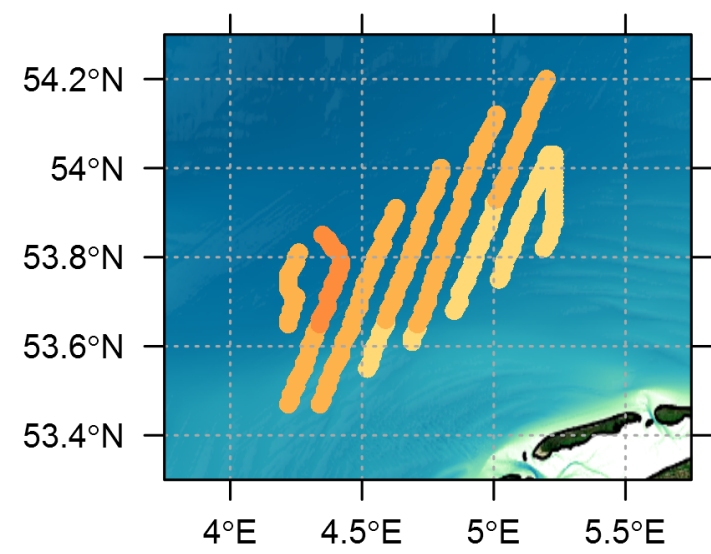

0 - spiegelglad

1 - kleine golven

2 - kleine korte golven

3 - kleine golven met kleine schuimkoppen

4 - golven iets langer, veel schuimkoppen

5 - matige golven met opwaaiend schuim

6 - matige golven met veel opwaaiend schuim

7 - grote golven met schuimstrepen

8 - zeer grote golven met schuimvelden
Seastate

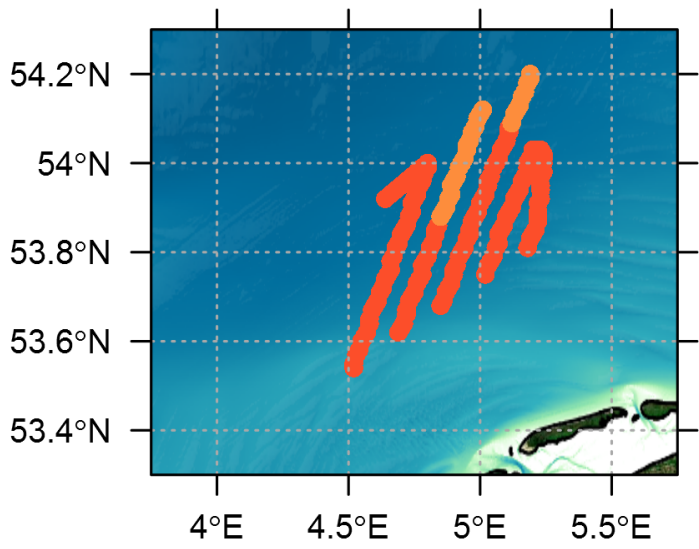

0 - spiegelglad

1 - kleine golven

2 - kleine korte golven

3 - kleine golven met kleine schuimkoppen

4 - golven iets langer, veel schuimkoppen

5 - matige golven met opwaaiend schuim

6 - matige golven met veel opwaaiend schuim

7 - grote golven met schuimstrepen

8 - zeer grote golven met schuimvelden

Figuur 2. Waarnemingsomstandigheden tijdens de surveys: links juli, rechts november. Weergegeven is de zeestaat.

Tabel 2. Waarnemingsinspanning per zeestaat; weergegeven is het aantal 5-mintellingen, de getelde oppervlakte en de getelde afstand.

\begin{tabular}{|c|c|c|c|}
\hline Zeestaat & 5-min telling & Oppervlak $\left(\mathrm{km}^{2}\right)$ & Afstand (km) \\
\hline \multicolumn{4}{|c|}{ Friese Front juli } \\
\hline 1 & - & - & - \\
\hline 2 & - & - & - \\
\hline 3 & 468 & 188.3 & 627.7 \\
\hline 4 & 134 & 53.3 & 177.6 \\
\hline 5 & 78 & 32.0 & 106.6 \\
\hline 6 & 16 & 6.3 & 21.0 \\
\hline Totaal & 910 & 368.4 & 1228.0 \\
\hline \multicolumn{4}{|c|}{ Friese Front november } \\
\hline 1 & - & - & - \\
\hline 2 & - & - & - \\
\hline 3 & - & - & - \\
\hline 4 & 36 & 17.4 & 58.0 \\
\hline 5 & 236 & 114.4 & 381.3 \\
\hline 6 & - & - & - \\
\hline Totaal & 272 & 131.8 & 439.3 \\
\hline
\end{tabular}

De omstandigheden tijdens de tellingen op het Friese Front in juli en november varieerden sterk. Tijdens de julitelling waren de omstandigheden subtropisch, met hoge temperaturen, felle zon en een zeestaat van maximaal 6 Beaufort. In juli waren de omstandigheden op het Friese Front goed tijdens $90 \%$ van de 5-mintellingen. Tijdens de overige tellingen waren de omstandigheden met een zeestaat van minstens 5 Beaufort over het algemeen matig (tabel 2). Tijdens de novembertellingen waren de omstandigheden matig tot slecht met een zeestaat van 4 of 5 Beaufort of meer. Het grootste deel van de tellingen $(87 \%)$ werd uitgevoerd in zeestaat 5. 


\subsection{Overzicht van de waarnemingen}

Een gedetailleerd overzicht van de waargenomen vogels, zeezoogdieren en overige opmerkelijke zaken tijdens de twee surveys is weergegeven in de bijlagen. Hierin worden ook de aantallen 5-min tellingen zonder waarnemingen en sporen van menselijk handelen (staand want, ballonnen) weergegeven. Nota bene: de getelde aantallen zijn niet hetzelfde als de aantallen vogels die totaal in het gebied aanwezig waren omdat het hier slechts een steekproef betreft.

Tijdens de eerste survey op het Friese Front in juli werden 13650 individuen van 25 verschillende vogelsoorten geteld. Zeekoet $(n=6127)$, Kleine Mantelmeeuw $(n=2680)$, Drieteenmeeuw $(n=1544)$, Noordse Stern/Visdief $(n=1176)$ en Jan-van-Gent $(n=1175)$ domineerden de telling. Daarnaast werden 143 individuen verdeeld over drie soorten zeezoogdieren (Dwergvinvis, Bruinvis en Grijze Zeehond) geregistreerd.

Tijdens de tweede survey op het Friese Front in november werden 1864 individuen verdeeld over 15 verschillende vogelsoorten geteld. Zeekoet $(n=717)$, Alk $(n=697)$ en Drieteenmeeuw $(n=190)$ waren de dominante soorten. Daarnaast werden vijf Bruinvissen gezien.

\subsection{Soortbesprekingen}

\subsubsection{Noordse Stormvogel}

$\begin{array}{lll} & \text { jul-FF } & \text { nov-FF } \\ \text { Aantal } & 534 & 0\end{array}$

Noordse Stormvogels werden alleen tijdens de julisurvey gezien. In november ontbrak de soort op het Friese Front. De verspreiding was onregelmatig, maar de meeste vogels werden in het noordelijk deel van het gebied gezien. Dit werd deels veroorzaakt door de aanwezigheid van viskotters in een deel van het gebied. Een groot deel van de Noordse Stormvogels $(37 \%, n=534)$ was geassocieerd met een actieve kotter; een kleiner percentage volgde het onderzoeksschip $(1 \%, n=534)$. Alle vogels waarvan de kleurfase vastgesteld kon worden $(n=284)$, behoorden tot de lichte kleurfase.

\section{Noordse Stormvogel}

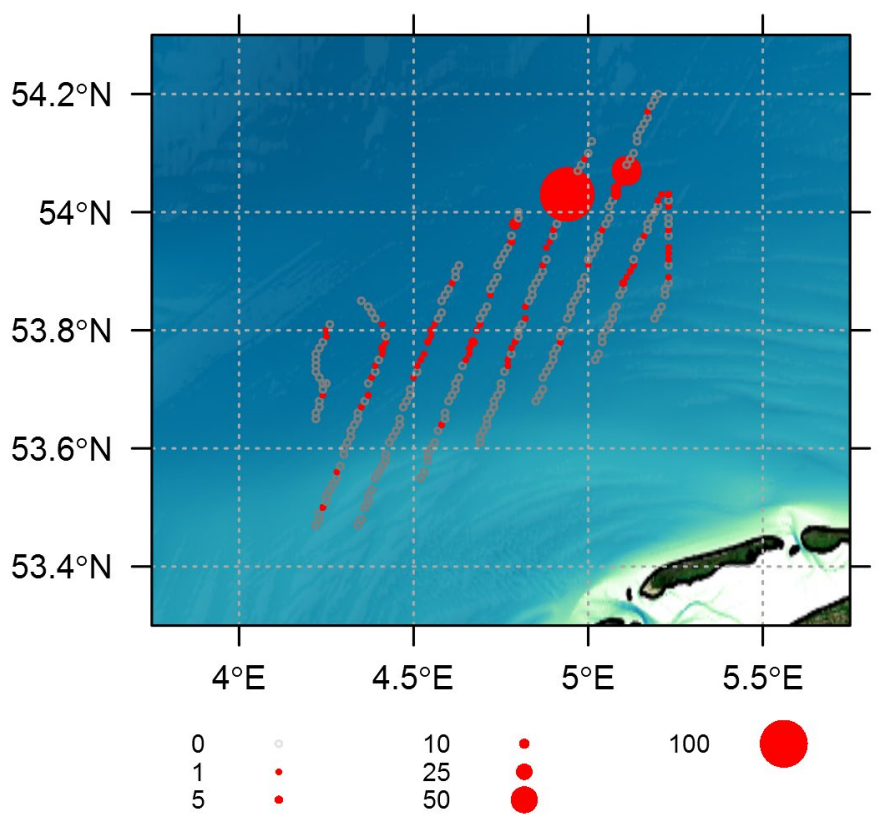

Figuur 3. Verspreiding van Noordse Stormvogel tijdens de survey op het Friese Front 24-28 juli 2018. Weergegeven zijn de gemiddelde aantallen per 5-mintelling. 


\subsubsection{Jan-van-Gent}

$\begin{array}{lcc} & \text { jul-FF } & \text { nov-FF } \\ \text { Aantal } & 1175 & 37\end{array}$

Jan-van-Genten behoorde tijdens de julisurvey tot de dominante soorten, in november waren de aantallen laag. De waarnemingen leken in november geconcentreerd in het centrale deel van het Friese Front (maar het westelijke deel van het gebied kon niet worden geteld). In juli werden Jan-van-Genten in het gehele gebied gezien, met uitzondering van het zuidwestelijke en noordoostelijke deel. Het beeld wordt deels bepaald door associaties van grotere groepen met actieve viskotters $(11 \%, n=1175)$. Opvallend was het hoge percentage met drijvende houten pallets geassocieerde Jan-van-Genten ( $9 \%)$. Doorgaans staan er een of twee vogels op een pallet en zwemt er een handvol vogels naast. Nu werden meerdere op een pallet gezien met maximaal 17 en 29 geassocieerde dieren. Een klein aantal individuen was geassocieerd met het onderzoeksschip (1\%) of een gas productie platform (1\%). Een kleiner percentage bestond uit associaties van Jan-van-Genten en zeezoogdieren $(<1 \%)$. Op 25 juli werd een groep bestaand uit negen bruinvissen, 25 duikende Jan-van-Genten en 15 zoekende Drieteenmeeuwen gezien. Daarnaast werd een zoekende Jan-van-Gent geassocieerd met een Bruinvis gezien. In juli waren adulte vogels in de minderheid $(44 \%, n=620)$. Het gros van de onvolwassen vogels $(52 \%, n=345)$ was eerste of tweedejaars. Oudere onvolwassen dieren waren minder talrijk. In november waren onvolwassen vogels in de minderheid $(11 \%, n=28)$

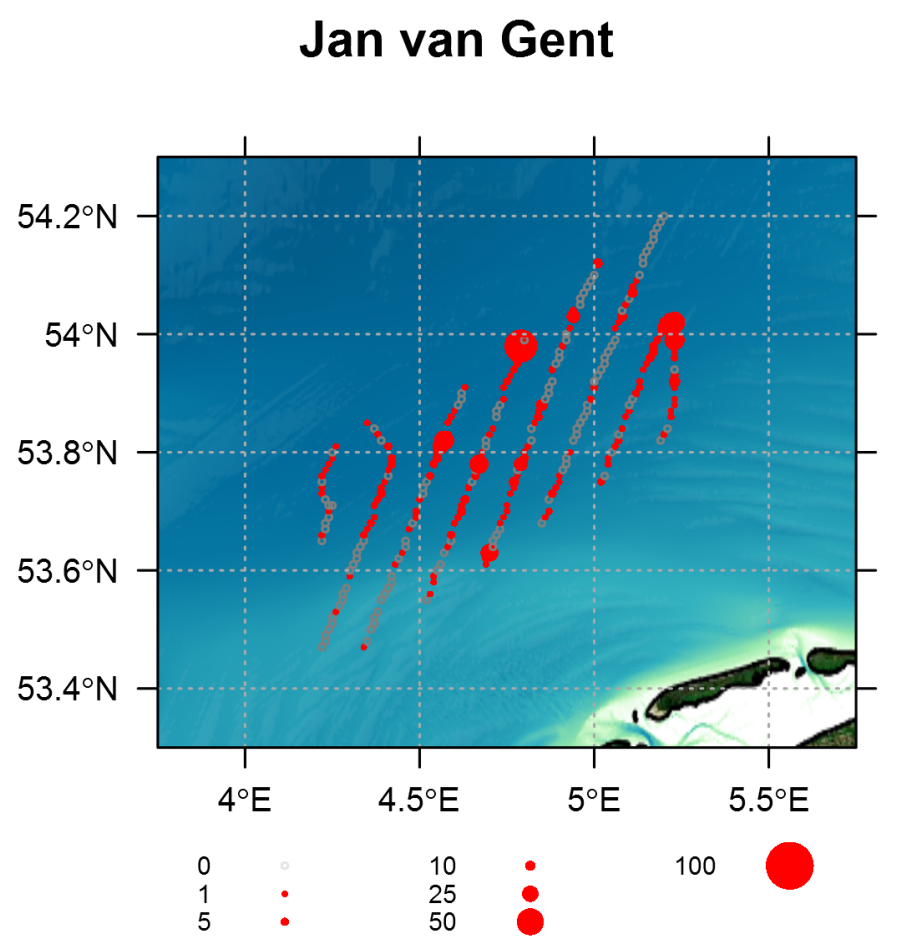

Figuur 5. Verspreiding van Jan-van-Gent tijdens de survey op het Friese Front 24-28 juli 2018. Weergegeven zijn de gemiddelde aantallen per 5-mintelling. 


\section{Jan van Gent}

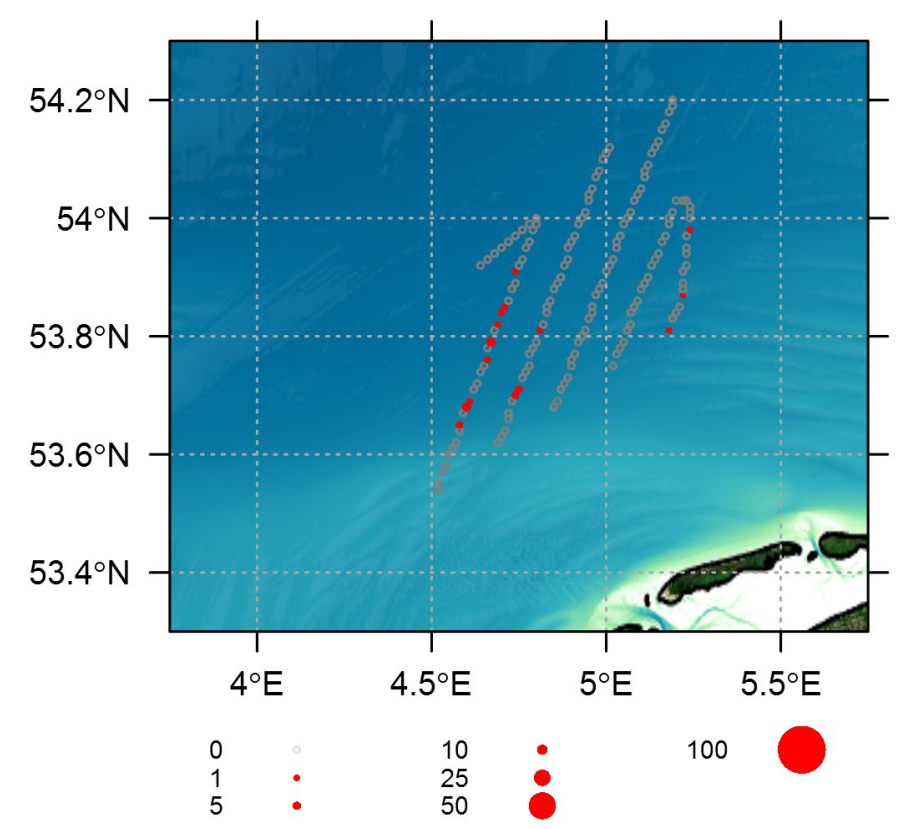

Figuur 6. Verspreiding van Jan-van-Gent tijdens de survey op het Friese Front 25-28 november 2018. Weergegeven zijn de gemiddelde aantallen per 5-mintelling.

\subsubsection{Zwarte Zee-eend}

$\begin{array}{lll} & \text { jul-FF } & \text { nov-FF } \\ \text { Aantal } & 16 & 0\end{array}$

Zwarte Zee-eenden werden slechts twee keer gezien. Twee groepjes werden in juli in westelijke richting vliegend gezien.

\section{Zwarte Zee-eend}

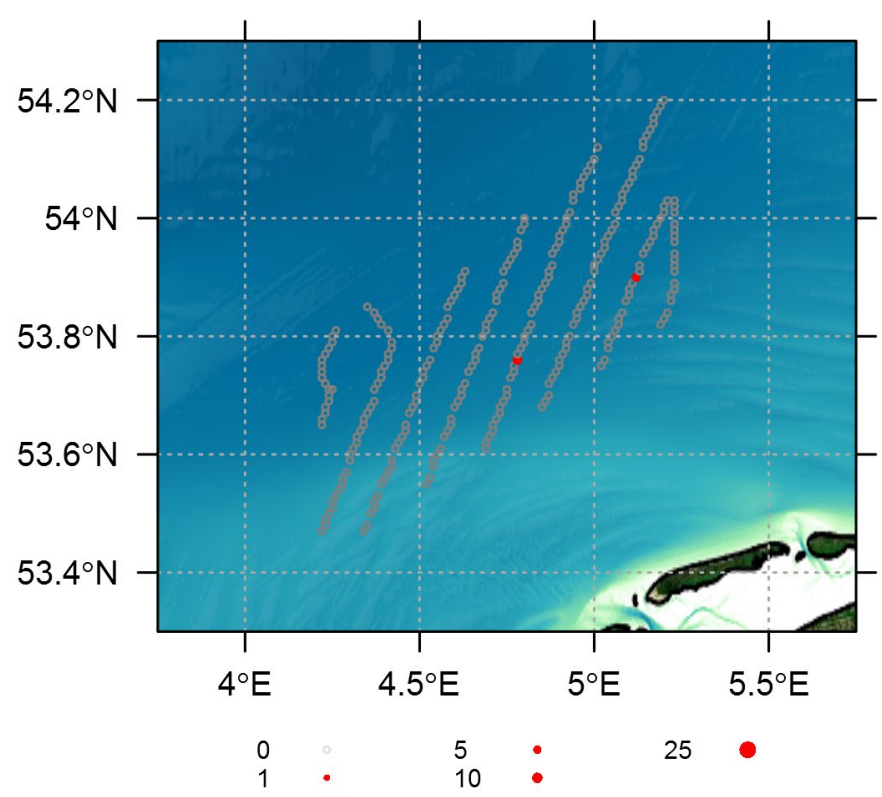

Figuur 7. Verspreiding van Zwarte Zee-eend tijdens de survey op het Friese Front 24-28 juli 2018. Weergegeven zijn de gemiddelde aantallen per 5-mintelling. 


\subsubsection{Grote Jager}

$\begin{array}{lll} & \text { jul-FF } & \text { nov-FF } \\ \text { Aantal } & 11 & 0\end{array}$

Grote Jagers werden uitsluitend in juli gezien. Meer dan de helft van de vogels vloog langs. Een individu was geassocieerd met een actieve viskotter met een volgwolk bestaand uit Noordse Stormvogel (10), Jan-van-Gent (64), Kleine Jager (1), Kleine Mantelmeeuw (480), Grote Mantelmeeuw (21) en Drieteenmeeuw (2). Vier andere Grote Jagers joegen achter Jan-van-Genten, Kleine Mantelmeeuwen of Drieteenmeeuwen aan.

\section{Grote Jager}

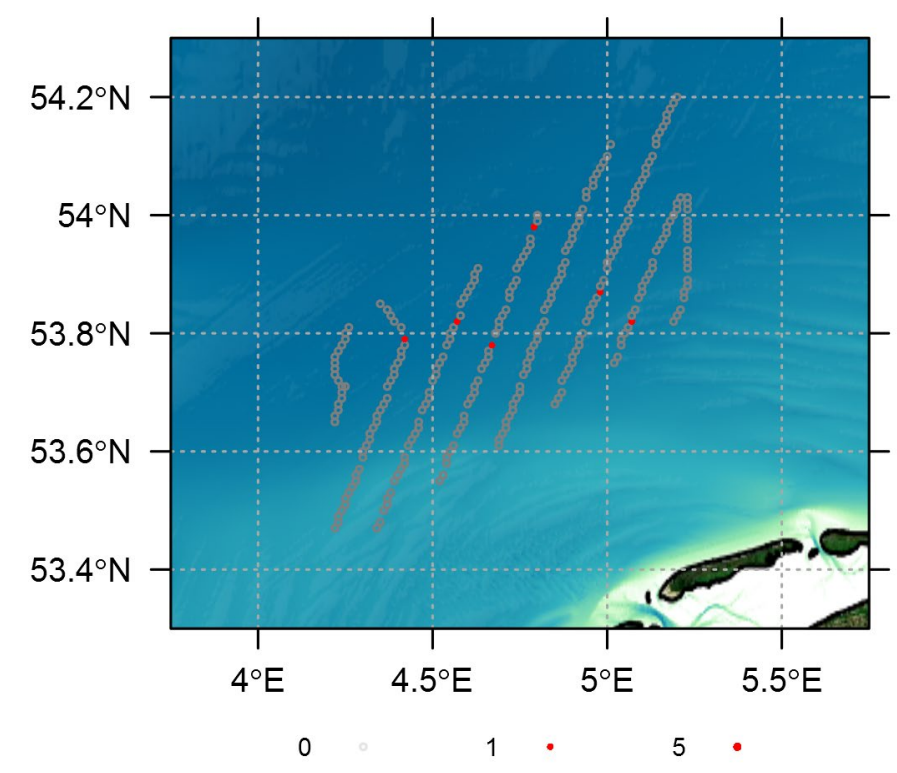

Figuur 8. Verspreiding van Grote Jager tijdens de survey op het Friese Front 24-28 juli 2018. Weergegeven zijn de gemiddelde aantallen per 5-mintelling.

\subsubsection{Kleine Mantelmeeuw}

$\begin{array}{lll} & \text { jul-FF } & \text { nov-FF } \\ \text { Aantal } & 2680 & 0\end{array}$

Kleine Mantelmeeuwen waren in juli een van de dominante soorten op het Friese Front. In november werd de soort niet meer gezien. De meeste vogels waren in juli geassocieerd met vissende kotters ( $81 \%$, $\mathrm{n}=2680$ ), waarbij ze in het zog van de kotters aan het foerageren waren. Een klein aandeel $(1 \%)$ foerageerde op natuurlijke voedselbronnen (cf Baptist et al. 2019). De verspreiding wordt dan ook gedomineerd door vogels die bij viskotters 'rond hingen'.

Het merendeel van de op leeftijd gebrachte vogels was volwassen ( $92 \%$ adult, $n=299$ ). De overige vogels waren eerstejaars, geboren in 2017. 


\section{Kleine Mantelmeeuw}

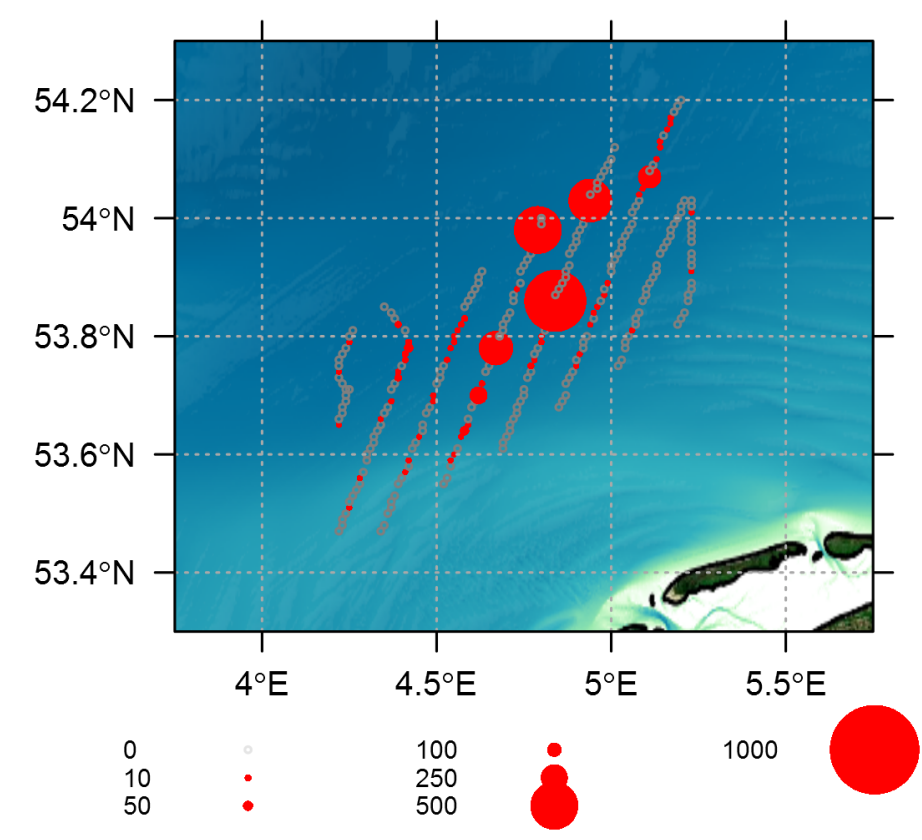

Figuur 9. Verspreiding van Kleine Mantelmeeuw tijdens de survey op het Friese Front 24-28 juli 2018. Weergegeven zijn de gemiddelde aantallen per 5-mintelling.

\subsubsection{Grote Mantelmeeuw}

$\begin{array}{lll} & \text { jul-FF } & \text { nov-FF } \\ \text { Aantal } & 89 & 37\end{array}$

\section{Grote Mantelmeeuw}

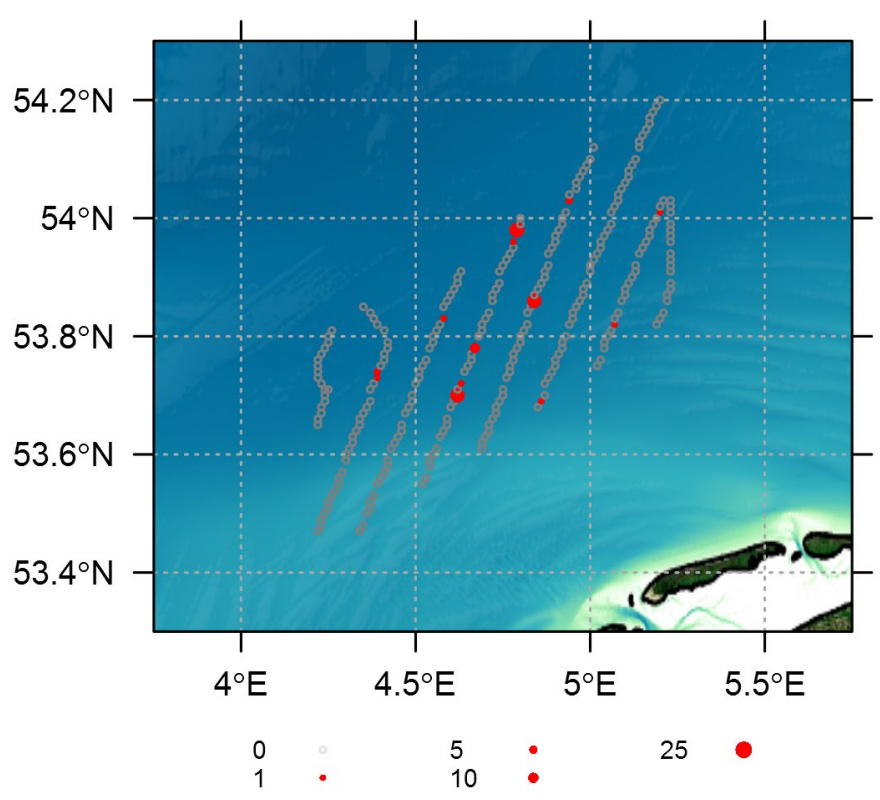

Figuur 10. Verspreiding van Grote Mantelmeeuw tijdens de survey op het Friese Front 24-28 juli 2018. Weergegeven zijn de gemiddelde aantallen per 5-mintelling. 
In tegenstelling tot Kleine Mantelmeeuw werden Grote Mantelmeeuwen in beide perioden gezien. De aantallen waren in beide perioden laag. De verspreiding was onregelmatig en werd sterk bepaald door menselijke activiteit; 44\% was geassocieerd met viskotters en 30\% met gasproductie platforms ( $n=$ 126). In juli was het gros van de vogels onvolwassen ( $76 \%, n=13$ op leeftijd gebrachte individuen), in november was het merendeel volwassen $(75 \%, \mathrm{n}=16)$.

\section{Grote Mantelmeeuw}

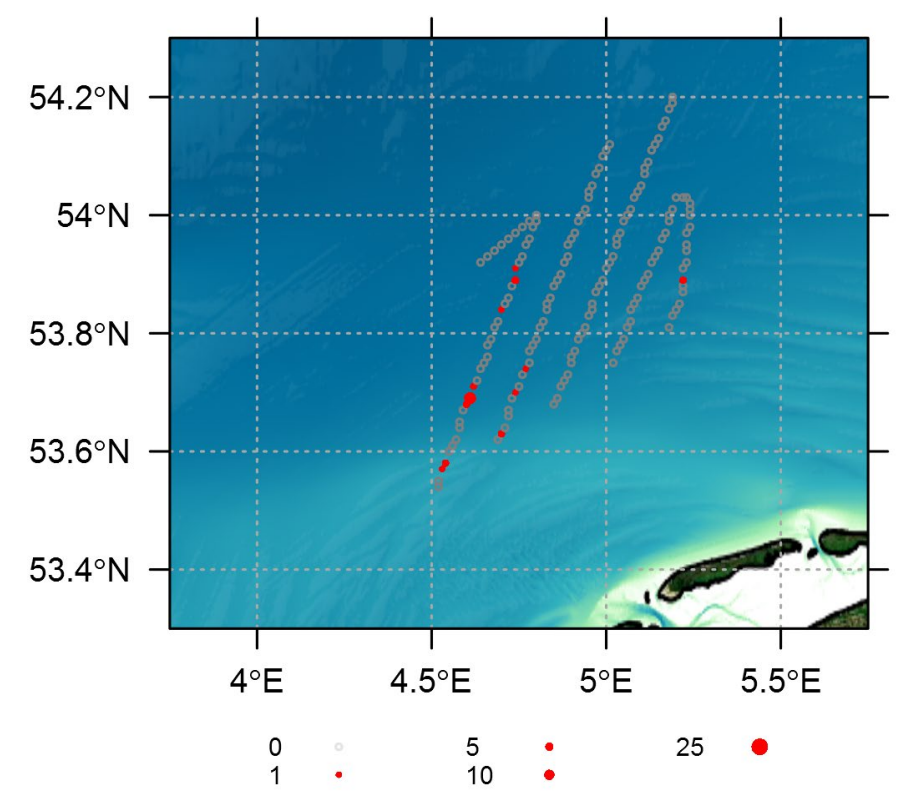

Figuur 11. Verspreiding van Grote Mantelmeeuw tijdens de survey op het Friese Front 25-28 november 2018. Weergegeven zijn de gemiddelde aantallen per 5-mintelling.

\subsubsection{Drieteenmeeuw}

$\begin{array}{lll} & \text { jul-FF } & \text { nov-FF } \\ \text { Aantal } & 1544 & 190\end{array}$

Drieteenmeeuwen werden tijdens beide surveys gezien. De hoogste aantallen werden in juli gezien. De verspreiding van Drieteenmeeuwen werd in deze maand grotendeels bepaald door menselijke activiteiten. In juli was een groot deel van de vogels geassocieerd met een gasproductie platform (40\%, $\mathrm{n}=1544)$ of een viskotter $(3 \%)$. Een lager percentage vogels (5\%) was geassocieerd met (foeragerende) bruinvissen ( $n=11$ of Zeekoeten $(n=49)$. Vermeldenswaard is de waarneming op 26 juli van broedende Drieteenmeeuwen op het L6-B platform aan de zuidkant van het Friese Front. Aan de hand van foto's werden minstens 13 nesten geteld.

In november waren Drieteenmeeuwen niet of nauwelijks aan menselijke activiteiten gebonden, maar was $35 \%$ geassocieerd met foeragerende alkachtigen $(n=105)$. Op een groep ongedetermineerde alkachtigen en een Zeekoet na, bestonden alle associaties uit Drieteenmeeuwen en Alken $(n=64)$. De meeste daarvan bestonden alleen uit Alken, bij drie daarvan $(n=17)$ waren ook Zeekoeten $(n=6)$ aangesloten. Een Drieteenmeeuw werd zoekend boven een Bruinvis waargenomen. De verspreiding in november was dan ook gelijkmatiger dan in juli.

Het merendeel van de waargenomen Drieteenmeeuwen was adult, respectievelijk $99 \%(n=446)$ in juli en $83 \%(n=143)$ in november. 
Drieteenmeeuw

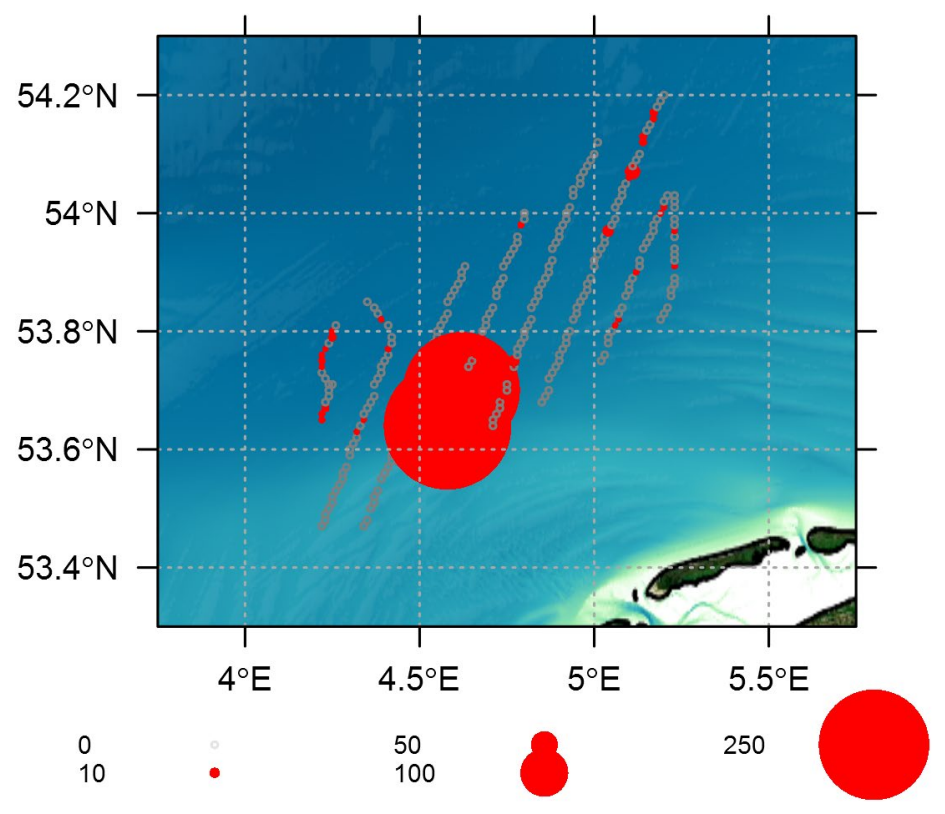

Figuur 12. Verspreiding van Drieteenmeeuw tijdens de survey op het Friese Front 24-28 juli 2018. Weergegeven zijn de gemiddelde aantallen per 5-mintelling.

\section{Drieteenmeeuw}

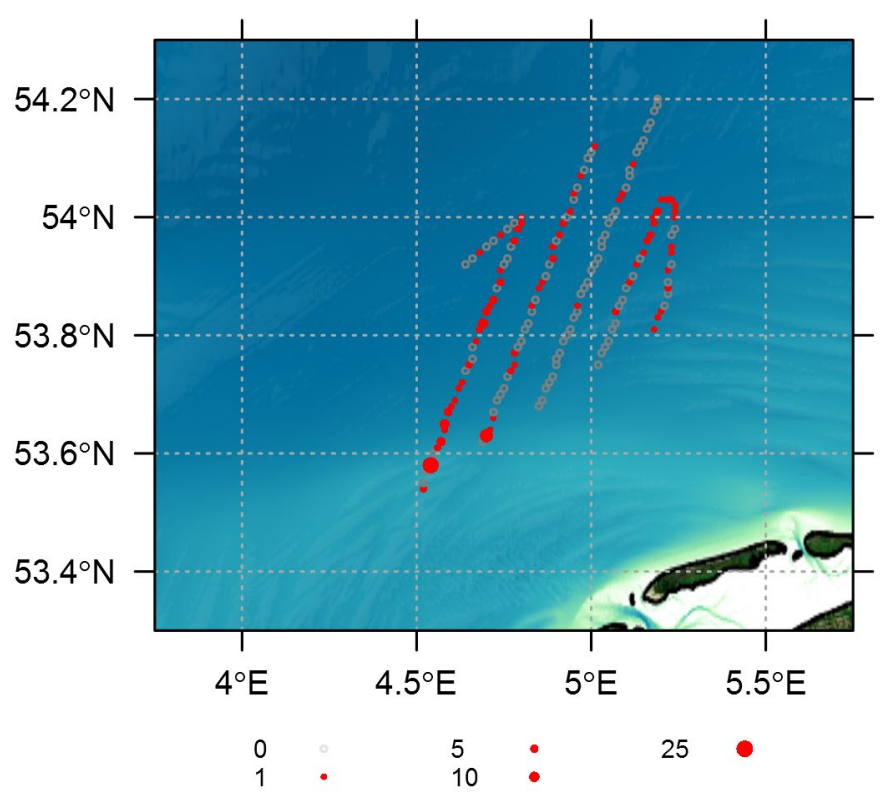

Figuur 13. Verspreiding van Drieteenmeeuw tijdens de survey op het Friese Front 25-28 november 2018. Weergegeven zijn de gemiddelde aantallen per 5-mintelling. 


\subsubsection{Alk}

$\begin{array}{lll} & \text { jul-FF } & \text { nov-FF } \\ \text { Aantal } & 0 & 697\end{array}$

Alken werden uitsluitend tijdens de novembersurvey op het Friese Front gezien. De verspreiding was onregelmatig. Op de eerste dag werden lage dichtheden op de oostelijke transecten gezien. Een dag later werden meer naar het westen hogere dichtheden gezien. De meest westelijke transecten konden niet geteld worden.

Op een individu in overgangskleed na, waren de vogels allemaal in winterkleed $(n=635)$.

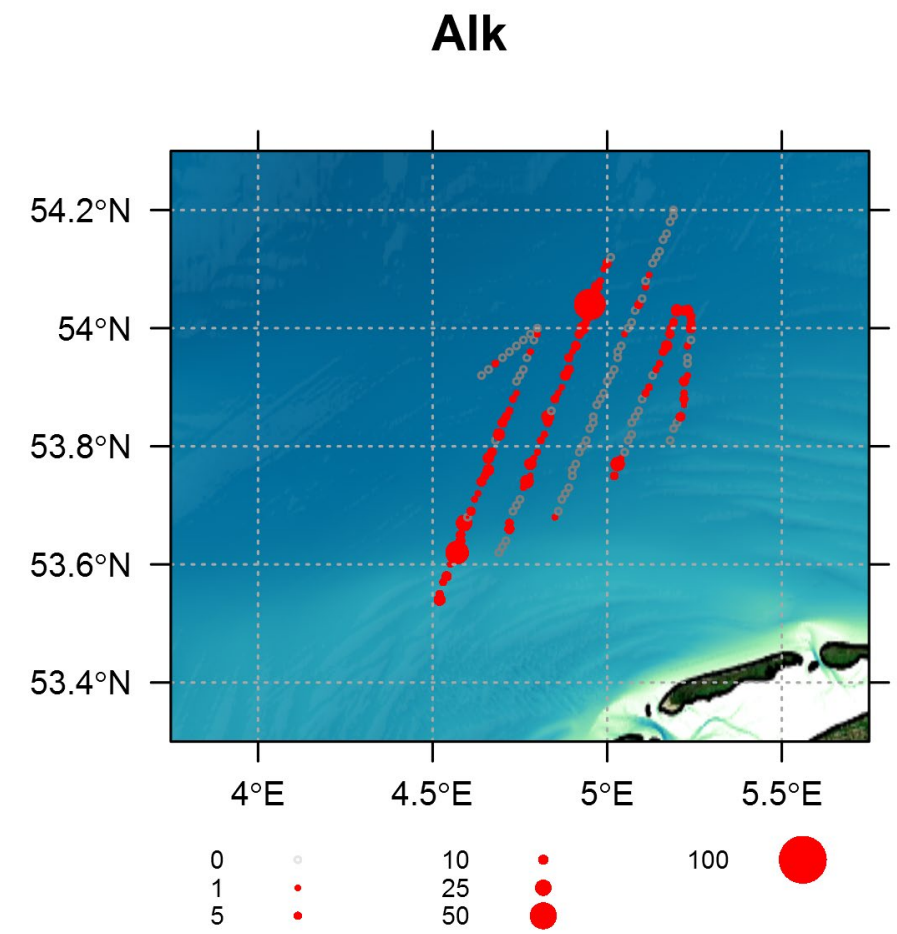

Figuur 14. Verspreiding van Alk tijdens de survey op het Friese Front 25-28 november 2018. Weergegeven zijn de gemiddelde aantallen per 5-mintelling.

\subsubsection{Zeekoet}

$\begin{array}{lll} & \text { jul-FF } & \text { nov-FF } \\ \text { Aantal } & 6127 & 717\end{array}$

Zeekoeten werden tijdens beide surveys in het hele onderzoeksgebied aangetroffen, met her en der hogere concentraties en elders lege gebieden. Zowel juli als november was Zeekoet op het Friese Front de talrijkste soort. In juli werden de hoogste aantallen in een oost-westlopende band in het centrale deel van het gebied gezien: een "zeekoetenfront". Buiten deze band was de verspreiding gelijkmatig. In juli was het aandeel vogels in broedkleed op het Friese Front 64\% ( $n=2983)$. Als de kuikens buiten beschouwing worden gelaten $(n=453)$ dan bedraagt het aandeel vogels in zomerkleed $75 \%$. Van de overige dieren was $19 \%$ in overgangskleed en $5 \%$ in winterkleed $(n=2530)$. In januari was het aandeel vogels in winterkleed opgelopen tot $96 \%(n=622)$ en was een handvol vogels in overgangs- of in zomerkleed.

De verhouding tussen Alken en Zeekoeten verschillende per survey. In juli werden op het Friese Front uitsluitend Zeekoeten gezien (tabel 3). Het aandeel ongedetermineerde Alk/Zeekoeten $(9 \%, n=1479$ ) in november was relatief hoog en werd veroorzaakt door de matige tot slechte surveyomstandigheden, waardoor relatief veel groepjes ver voor het schip uit opstegen en wegvlogen. Afhankelijk van de afstand en wegvliegrichting konden niet alle vogels op soort gedetermineerd worden. 
Tabel 3. Verhouding tussen aantallen Alken en Zeekoeten per survey.

\begin{tabular}{lll}
\hline & jul-FF & nov-FF \\
\hline Alk & 0 & 697 \\
Alk/Zeekoet & 0 & 65 \\
Zeekoet & 6127 & 717 \\
Alk:Zeekoet & $1: \infty$ & $1: 1.0$ \\
\hline
\end{tabular}

\section{Zeekoet}

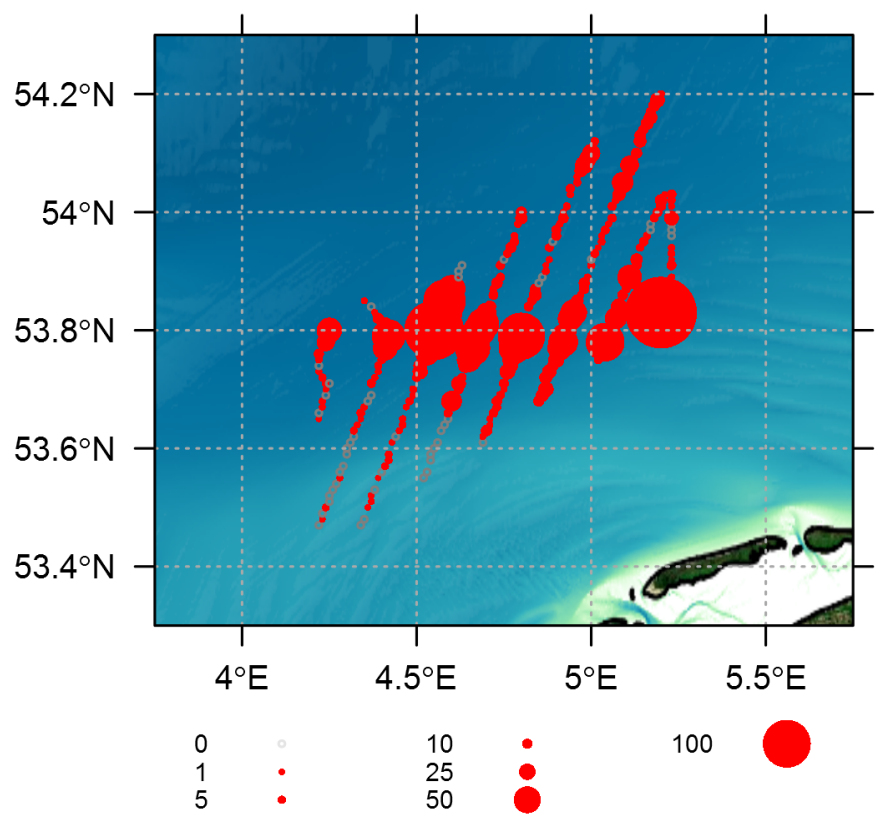

Figuur 15. Verspreiding van Zeekoet tijdens de survey op het Friese Front 24-28 juli 2018. Weergegeven zijn de gemiddelde aantallen per 5-mintelling.

\section{Zeekoet}

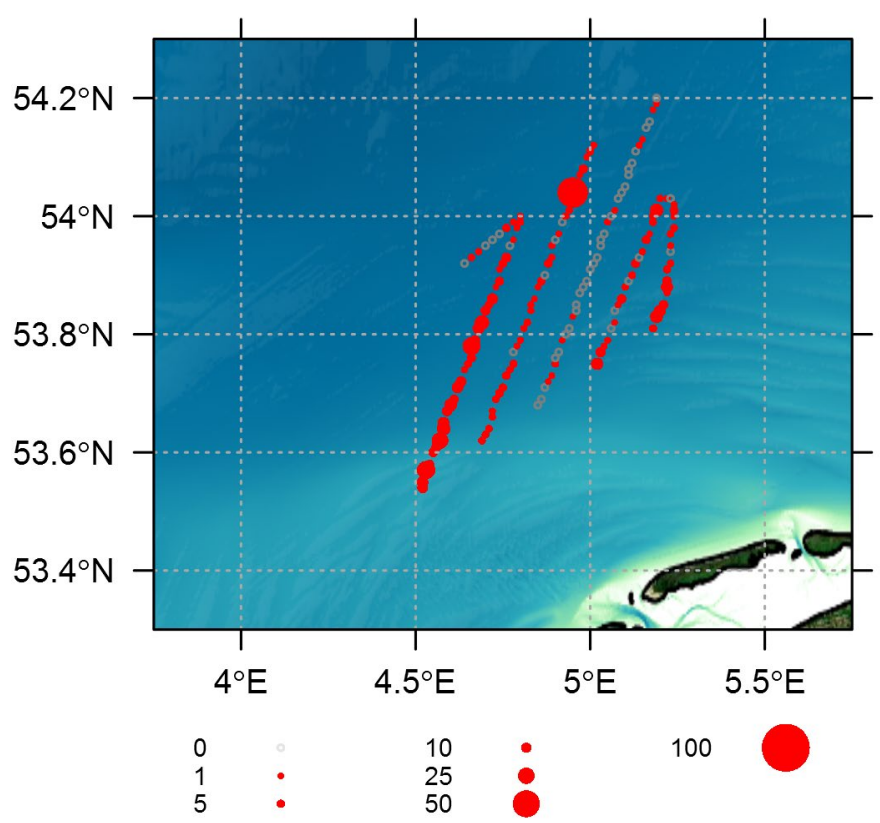

Figuur 16. Verspreiding van Zeekoet tijdens de survey op het Friese Front 25-28 november 2018. Weergegeven zijn de gemiddelde aantallen per 5-mintelling. 


\subsubsection{Bruinvis}

$\begin{array}{lll} & \text { jul-FF } & \text { nov-FF } \\ \text { Aantal } & 131 & 5\end{array}$

Bruinvissen werden tijdens beide surveys gezien. De getelde aantallen en daarmee de geschetste verspreiding waren sterk afhankelijk van de waarnemingsomstandigheden. De lage aantallen op het Friese Front in november zijn ongetwijfeld mede een gevolg van de slechte omstandigheden (zeestaat $\geq 5$ Beaufort).

De meeste Bruinvissen (63\%) werden als rustig zwemmend genoteerd; een kleiner aandeel (1\%) werd als schip mijdend of als snel zwemmend $(14 \%, \mathrm{n}=133)$ gekwalificeerd. Een zestal dieren werd met een kalfje gezien. Een aantal bruinvissen werd als foeragerend genoteerd $(9 \%, n=133)$, waaronder een groep van negen dieren op 25 juli vergezeld door 25 duikende Jan-van-Genten en 15 zoekende Drieteenmeeuwen.

\section{Bruinvis}

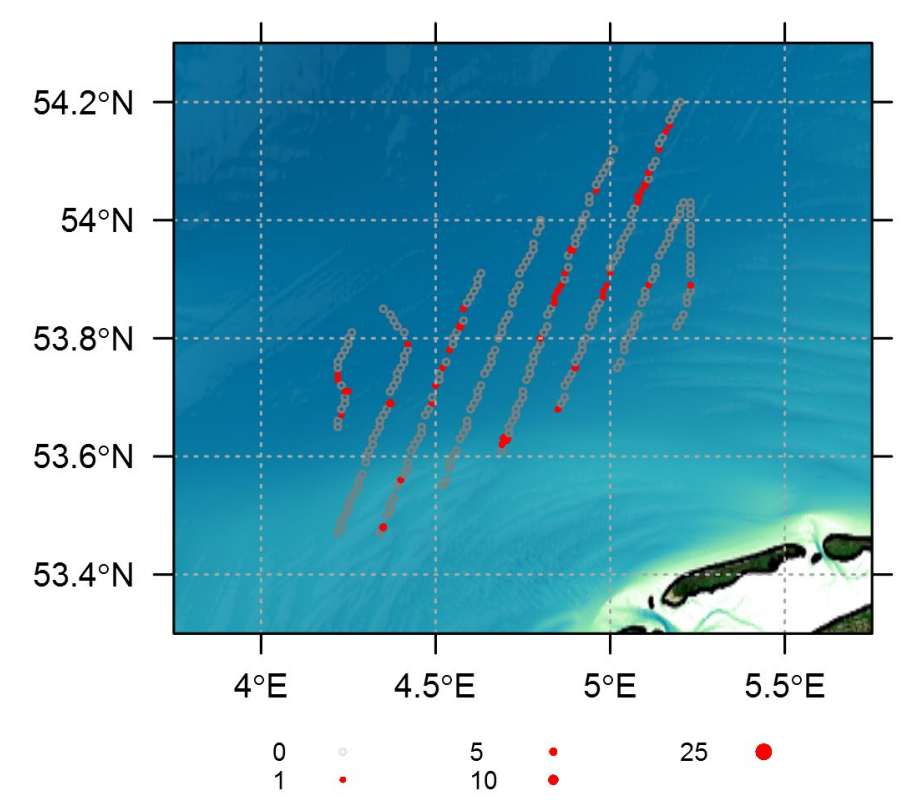

Figuur 17. Verspreiding van Bruinvis tijdens de survey op het Friese Front 24-28 juli 2018. Weergegeven zijn de gemiddelde aantallen per 5-mintelling. 


\section{Bruinvis}

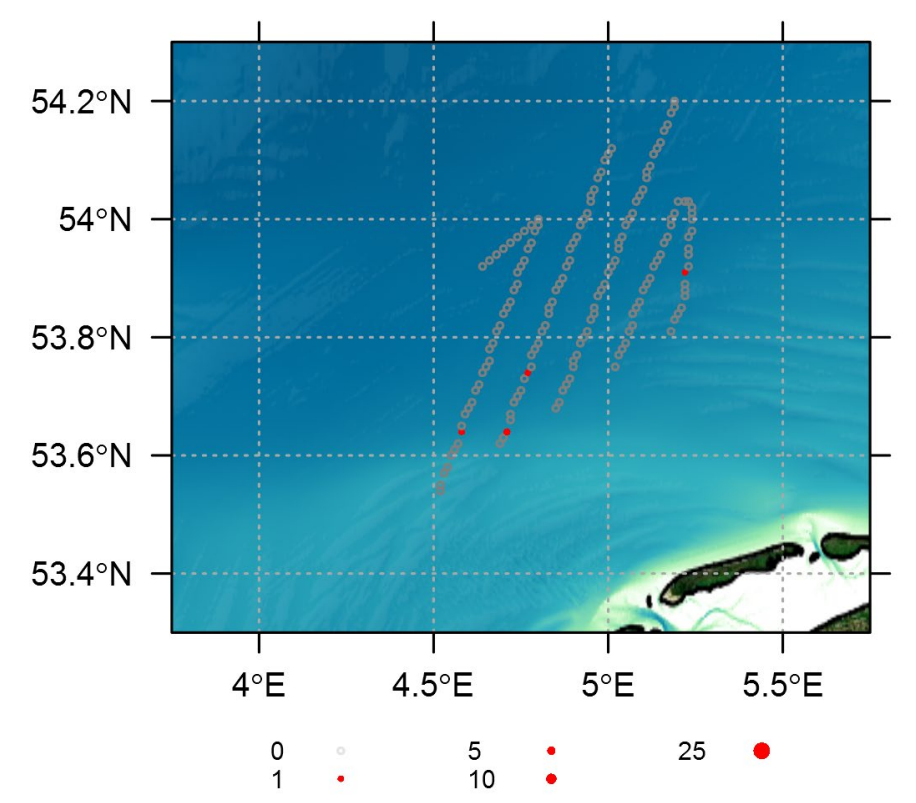

Figuur 18. Verspreiding van Bruinvis tijdens de survey op het Friese Front 25-28 november 2018. Weergegeven zijn de gemiddelde aantallen per 5-mintelling. 


\section{Conclusies en aanbevelingen}

In 2018 zijn twee surveys op het Friese Front uitgevoerd. Tijdens deze surveys behoorden Alk en Zeekoet tot de talrijkste soorten. In juli werden de hoogste aantallen Zeekoeten op het Friese Front geteld, terwijl Alken hier ontbraken. De verhouding Alk:Zeekoet was in november vrijwel gelijk, maar niet alle transecten konden geteld worden en met name Alken waren onregelmatig over het gebied verspreid.

Behalve van alkachtigen werden - zoals verwacht- aanvullende gegevens verzameld over de aantallen van potentieel kwalificerende N2000-soorten Grote Mantelmeeuw en Kleine Mantelmeeuw (met name juli). De aantallen van de potentieel kwalificerende N2000-soort Grote Jager waren tijdens beide surveys laag: dit is een soort die in Nederlandse wateren het talrijkst is tijdens de najaarstrek.

Vermeldenswaard is de waarneming van een kolonie Drieteenmeeuwen. Tijdens de julisurvey werden op een platform ten zuiden van het Friese Front minstens 13 nesten vastgesteld.

De getelde aantallen zijn niet hetzelfde als de aantallen vogels die totaal in het gebied aanwezig waren omdat het hier slechts een steekproef betreft. De omrekening naar totale aantallen aanwezig in de geïnventariseerde gebieden volgt in de eindrapportage. 


\section{Literatuur}

Baptist MJ, Bemmelen RSA van, Leopold MF, Haan D de, Flores H, Couperus B \& Faschler S \& Geelhoed SCV, 2019. Self-foraging vs facilitated foraging by Lesser Black-backed Gull (Larus fuscus) at the Frisian Front, the Netherlands. Bulletin of Marine Science 95(1): 29-43. DOI: 10.5343/bms.2017.1179

Bemmelen RSA van, Leopold MF \& Bos OG, 2012. Vogelwaarden van de Bruine Bank. Project Aanvullende Beschermde Gebieden (http://edepot.wur.nl/247418). Report C138/12, IMARES.

Camphuysen CJ \& Garthe S, 2004. Recording foraging seabirds at sea: standardised recording and coding of foraging behaviour and multi-species foraging associations. Atlantic Seabirds 6(1): 1-32.

Geelhoed SCV, Bos OG, Burggraaf D, Couperus AS \& Lagerveld S, 2014. Verklarende factoren voor de verspreiding van alken en zeekoeten op de Bruine Bank - Project Aanvullende Beschermde Gebieden Noordzee. IMARES Rapport C113.14.

Geelhoed SCV, \& Leopold MF, 2017. Cruiserapport scheepstellingen van zeevogels op het Friese Front en op de Bruine Bank, 2016. Wageningen Marine Research Wageningen UR (University \& Research centre), Wageningen Marine Research rapport C032/17.

Geelhoed SCV, Lagerveld S, Leopold MF \& JP Verdaat, 2018. Cruiserapport scheepstellingen van zeevogels op het Friese Front en op de Bruine Bank, 2017. Wageningen Marine Research Wageningen UR (University \& Research centre), Wageningen Marine Research rapport C035/18.

Leopold M, Bemmelen R van \& Geelhoed S, 2009. We@Sea Friese Front cruise, 27 juli \& 2-6 augustus 2009- Een samenvatting van de vogel- en zeezoogdiertellingen. Rapport IMARES.

Leopold MF \& Wal JT van der, 2015. Kwalificerende en niet-kwalificerende vogelsoorten in het gebied "Bruine Bank". Vertrouwelijk IMARES Rapport C015/16.

Leopold MF, Wal JT van der \& Scholl M, 2015. Kwalificerende en niet-kwalificerende vogelsoorten in het gebied "Friese Front". IMARES Rapport C141/15.

Lindeboom H, Geurts Kessel J van \& Berkenbosch L, 2005. Gebieden met bijzondere ecologische waarden op het Nederlands Continentaal Plat. Rapport RIKZ/2005.008, Alterra Rapport nr. 1109.

Skov H, Durinck J, Leopold MF \& Tasker ML, 2007. A quantitative method for evaluating the importance of marine areas for conservation of birds. Biological Conservation 136:362-371.

Tasker ML, Jones PH, Dixon TJ \& Blake BF, 1984. Counting seabirds at sea from ships: a review of methods employed and a suggestion for a standardized approach. Auk 101: 567-577. 


\section{Bijlagen Aantallen waargenomen vogels en zeezoogdieren}

Aantallen waargenomen vogels en zeezoogdieren per dag, Friese Front 24-28 juli 2018.

\begin{tabular}{|c|c|c|c|c|c|c|}
\hline & & 24 & 25 & 26 & 27 & Totaal \\
\hline Tellingen zonder vogels & Counts with no birds & 56 & 17 & 53 & 36 & 162 \\
\hline Noordse Stormvogel & Fulmarus glacialis & 11 & 246 & 64 & 213 & 534 \\
\hline Grauwe Pijlstormvogel & Puffinus griseus & 1 & 2 & & & 3 \\
\hline Noordse Pijlstormvogel & Puffinus puffinus & 1 & & 1 & 1 & 3 \\
\hline Jan van Gent & Sula bassana & 241 & 272 & 327 & 335 & 1175 \\
\hline Aalscholver & Phalacrocorax carbo & 1 & & & & 1 \\
\hline Wintertaling & Anas crecca & & & 2 & & 2 \\
\hline Zwarte Zee-eend & Melanitta nigra & & 16 & & & 16 \\
\hline Kanoetstrandloper & Calidris canutus & & & 9 & & 9 \\
\hline Steenloper & Arenaria interpres & 1 & & & & 1 \\
\hline Kleine Jager & Stercorarius parasiticus & & 2 & 2 & 1 & 5 \\
\hline Grote Jager & Stercorarius skua & 1 & 2 & 4 & 4 & 11 \\
\hline Kokmeeuw & Larus ridibundus & 1 & 2 & 2 & 11 & 16 \\
\hline Stormmeeuw & Larus canus & 1 & 1 & 4 & 2 & 8 \\
\hline Kleine Mantelmeeuw & Larus fuscus & 72 & 1384 & 1172 & 52 & 2680 \\
\hline Zilvermeeuw & Larus argentatus & 2 & & & 1 & 3 \\
\hline Grote Mantelmeeuw & Larus marinus & 4 & 27 & 57 & 1 & 89 \\
\hline \multicolumn{2}{|c|}{ ongedeterm. mantelmeeuw L. fuscus / L. marinus } & & & 40 & & 40 \\
\hline Drieteenmeeuw & Rissa tridactyla & 2 & 102 & 645 & 795 & 1544 \\
\hline Grote Stern & Sterna sandvicensis & 38 & 2 & & & 40 \\
\hline Visdief & Sterna hirundo & 129 & 136 & 39 & 1 & 305 \\
\hline Noordse Stern & Sterna paradisaea & 82 & 88 & 38 & 14 & 222 \\
\hline Visdief / Noordse Stern & S. hirundo / S. paradisaea & 57 & 288 & 298 & 6 & 649 \\
\hline Zeekoet & Uria aalge & 476 & 1834 & 1736 & 2081 & 6127 \\
\hline Gierzwaluw & Apus apus & & & & 4 & 4 \\
\hline Tjiftjaf / Fitis & P. collybita / P. trochilus & & & & 1 & 1 \\
\hline Dwergvinvis & Balaenoptera acutorostrata & & & 5 & & 5 \\
\hline Bruinvis & Phocoena phocoena & 15 & 59 & 31 & 26 & 131 \\
\hline Grijze Zeehond & Halichoerus grypus & 4 & 2 & 1 & & 7 \\
\hline \multicolumn{2}{|l|}{ staand want } & & & & & 1 \\
\hline \multirow{2}{*}{\multicolumn{2}{|c|}{$\begin{array}{l}\text { ballon } \\
\text { folie-ballon }\end{array}$}} & 1 & 4 & & 3 & 8 \\
\hline & & 1 & 7 & 4 & 2 & 14 \\
\hline & 1198 & 4493 & 4534 & 3590 & 13816 \\
\hline
\end{tabular}


Aantallen waargenomen vogels en zeezoogdieren per dag, Friese Front 26 -27 november 2018.

\begin{tabular}{llrrr}
\hline & & 26 & 27 & Totaal \\
\hline Tellingen zonder vogels & Counts with no birds & 56 & 6 & 62 \\
Roodkeelduiker & Gavia stellata & 1 & 2 & 3 \\
Vaal Stormvogeltje & Oceanodroma leucorhoa & 1 & & 1 \\
Jan van Gent & Sula bassana & 3 & 34 & 37 \\
Watersnip & Gallinago gallinago & & 1 & 1 \\
Dwergmeeuw & Larus minutus & 7 & & 7 \\
Kokmeeuw & Larus ridibundus & & 1 & 1 \\
Stormmeeuw & Larus canus & 21 & 15 & 36 \\
Zilvermeeuw & Larus argentatus & 4 & 4 & 8 \\
Grote Burgemeester & Larus hyperboreus & & 1 & 1 \\
Grote Mantelmeeuw & Larus marinus & 3 & 34 & 37 \\
Drieteenmeeuw & Rissa tridactyla & 44 & 146 & 190 \\
Zeekoet & Uria aalge & 202 & 515 & 717 \\
Alk / Zeekoet & Alca torda / Uria aalge & & 65 & 65 \\
Alk & Alca torda & 185 & 512 & 697 \\
Vink & Fringilla coelebs & 1 & & 1 \\
Bruinvis & Phocoena phocoena & 1 & 4 & 5 \\
folie-ballon & & 1 & & 1 \\
\hline & & 530 & 1340 & 1870 \\
\hline
\end{tabular}




\section{Kwaliteitsborging}

Wageningen Marine Research beschikt over een ISO 9001:2015 gecertificeerd kwaliteitsmanagementsysteem (certificaatnummer: 187378-2015-AQ-NLD-RvA). Dit certificaat is geldig tot 15 september 2018. De organisatie is gecertificeerd sinds 27 februari 2001. De certificering is uitgevoerd door DNV Certification B.V. 


\section{Verantwoording}

Rapport C098/19

Projectnummer: 4318100189

Dit rapport is met grote zorgvuldigheid tot stand gekomen. De wetenschappelijke kwaliteit is intern getoetst door een collega-onderzoeker en het verantwoordelijk lid van het managementteam van Wageningen Marine Research

Akkoord:

Dr. Ir. H.V. Winter

Onderzoeker

Handtekening:

Datum:

25 oktober 2019

Akkoord:

Drs. J. Asjes

Manager Integratie

Handtekening:

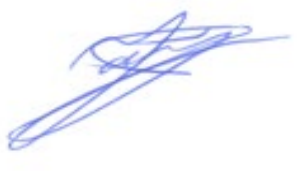

Datum:

25 oktober 2019 
Wageningen Marine Research

$\mathrm{T}:+31(0) 317480900$

E: marine-research@wur.nl

www.wur.nl/marine-research

Visitors address

- Ankerpark 27, 1781 AG Den Helder

- Korringaweg 5, 4401 NT Yerseke

- Haringkade 1, 1976 CP IJmuiden
Wageningen Marine Research is the Netherlands research institute established to provide the scientific support that is essential for developing policies and innovation in respect of the marine environment, fishery activities, aquaculture and the maritime sector.

Wageningen University \& Research is specialised in the domain of healthy food and living environment.

\section{The Wageningen Marine Research vision:}

'To explore the potential of marine nature to improve the quality of life.'

\section{The Wageningen Marine Research mission}

- To conduct research with the aim of acquiring knowledge and offering advice on the sustainable management and use of marine and coastal areas.

- Wageningen Marine Research is an independent, leading scientific research institute.

Wageningen Marine Research is part of the international knowledge organisation Wageningen UR (University \& Research centre). Within Wageningen UR, nine specialised research institutes of Stichting Wageningen Research (a Foundation) have joined forces with Wageningen University to help answer the most important questions in the domain of healthy food and living environment. 